\title{
SUMMER SEMINAR IN COSSACK FOLK MUSIC AT MOSCOW STATE CONSERVATORY
}

\section{Laura Olson, University of Colorado, Boulder}

The Folk Music Department of the Moscow State Conservatory announces its second summer seminar, The Singing and Instrumental Traditions of the Don Cossacks, to take place August 5-19, 1998. The seminar will include 6 days of workshops and courses at the Moscow Conservatory, and a 7-day field expedition to Cossack villages in the Volgograd region of Russia. Participants will live in home-stay situations: in Moscow, they will be housed with members of the Moscow State Conservatory Folklore Ensemble, and in the Volgograd area, in Cossack homes. Natalia Giliarova, the chair of the Folklore Department of the Conservatory and director of the Folklore Ensemble, will conduct the seminar. The specific hours of study included in the Moscow portion of the trip are:

-Basic genres of Russian folklore ( 4 hours)

-Singing traditions of the Don Cossacks (4 hours)

\section{-The Wedding ritual ( 2 hours)}

-Instrumental traditions of the Don Cossacks

(2 hours)

-Workshops in singing, instruments, and traditional dances and games, together with the Moscow Conservatory Folklore Ensemble. Includes group field trips to museums and parks in Moscow area (12 hours)

Lectures, classes, and all songs taught will be translated into English for those who do not know Russian. In living situations, every effort will be 
made to match non-Russian speakers with Englishspeaking hosts and/or roommates.

In Volgograd, participants will acquaint themselves with the traditions of the Don Cossacks directly from members of local amateur ensembles, and will have a chance to observe firsthand how traditions are carried out today. The Don Cossacks are Russian-speaking people who settled in the borderlands of Russia during the 16th century. They evolved particular traditions draivn from their unusual lifestyles and proximity to non-Russian peoples; their music has been made popular in Russia through the efforts of numerous revivalist groups, such as the Dmitri Pokrovsky Ensemble, which has extensively toured the U.S.

Both in Moscow and in Volgograd, participants will have ample opportunity to learn and practice songs and dances outside of scheduled classes. The seminar will be conducted informally with plenty of individual attention, so that students with particular interests can pursue them within the context of the seminar. All skill levels are welcome.

Cost of the entire seminar, including all living expenses, transportation within Russia, and classes, will be $\$ 1340$ if there is a total of 7-10 participants, and $\$ 1200$ if there are 10-15 participants. Supplementary cultural programs such as visits to specific museums or monuments in Moscow can be organized at the wish of the participants for modest extra cost.

Those who wish to take part in the seminar should send a letter to the Conservatory by May 1, 1998, with the following information, which is necessary for the issuance of the visa: Full name, date of birth, address, place of work or study, number of passport, its expiration date and date and place of issuance, and the desired dates for entry 
and exit of Russia. The letter should be sent by fax to: (7) (095) 229-9659 (write dlia Giliarovol on cover sheet) or by post to: Natalia Giliarova, Kabinet narodnoi muzyki, Moskovskaia Konservatoria, B. Nikitskaia 13, Moscow, Russia 103871. You may wish to call to make sure your fax or letter has been received; the home phone number of the seminar's organizer, Oksana Levko, is (7) (095) 138-1569.

For more information about the seminar, contact the co-organizer of the 1996 seminar: Prof. Laura Olson, Dept. of Germanic and Slavic, University of Colorado at Boulder, by e-mail at lolson@colorado.edu or phone (303) 492-7729. 